\title{
Three New Montane Forest Myrtaceae from Espírito Santo, Brazil
}

\author{
Marcos Sobral \\ Departamento de Ciências Naturais, Universidade Federal de São João del-Rei, Praça Dom \\ Helvécio 74, 36301-160 São João del-Rei, Minas Gerais, Brazil. marcos_sobral@hotmail.com
}

AbSTRACT. Three new species of Myrtaceae from montane forests of the southeastern Brazilian state of Espírito Santo are described, illustrated, and compared with related species: Eugenia crassa Sobral, Myrcia santateresana Sobral, and M. tumida Sobral. Eugenia crassa is closely affined to E. umbrosa 0 . Berg, from which it is set apart by the smaller and wider leaves (to $170 \times 75 \mathrm{~mm}$ in E. crassa vs. to 200 $\times 50 \mathrm{~mm}$ ), axillary inflorescences, and flowers with larger bracteoles (to $8 \mathrm{~mm}$ in E. crassa vs. to $2 \mathrm{~mm}$ ); M. santateresana is related to M. badia (O. Berg) N. Silveira, from which the new species differs by its smaller leaves (to $140 \times 50 \mathrm{~mm}$ in $M$. santateresana vs. to $200 \times 50 \mathrm{~mm}$ ) with discontinuous marginal veins and smaller (buds to $2 \mathrm{~mm}$ in $M$. santateresana vs. to $4 \mathrm{~mm}$ ), glabrous flowers without a calyx tube; $M$. tumida is close to M. guianensis (Aubl.) DC., differing by its swollen calyx lobes, larger fruits (to $18 \mathrm{~mm}$ in M. tumida vs. to $10 \mathrm{~mm}$ ), and longer petioles (to $13 \mathrm{~mm}$ in $M$. tumida vs. to $6 \mathrm{~mm}$ ).

Resumo. São descritas e ilustradas três novas espécies de Myrtaceae da floresta ombrófila montana do Espírito Santo, Brasil: Eugenia crassa Sobral, Myrcia santateresana Sobral e M. tumida Sobral. Eugenia crassa é próxima de E. umbrosa O. Berg, diferindo pelas folhas menores e mais largas (até $170 \times 75 \mathrm{~mm}$ em E. crassa vs. até $200 \times 50 \mathrm{~mm}$ ), inflorescências axilares e flores com bractéolas maiores (até $8 \mathrm{~mm}$ em $E$. crassa vs. até $2 \mathrm{~mm}$ ); M. santateresana é próxima a M. badia (O. Berg) N. Silveira, diferindo pelas folhas menores (até $140 \times$ $50 \mathrm{~mm}$ em M. santateresana vs. até $200 \times 50 \mathrm{~mm}$ ) com nervura marginal descontínua, flores glabras e menores (botões até $2 \mathrm{~mm}$ em $M$. santateresana vs. até $4 \mathrm{~mm}$ ) e tubo do cálice ausente; e $M$. tumida é próxima a $M$. guianensis (Aubl.) DC., da qual difere pelas flores com lobos do cálice engrossados, frutos maiores (até $18 \mathrm{~mm}$ em $M$. tumida vs. até $10 \mathrm{~mm}$ ) e pecíolos mais longos (até $13 \mathrm{~mm}$ em $M$. tumida vs. até $6 \mathrm{~mm}$ ).

Key words: Brazil, Espírito Santo, Eugenia, IUCN Red List, Myrcia, Myrtaceae.

The central region of the southeastern Brazilian state of Espírito Santo (ca. $19^{\circ} 30^{\prime}-20^{\circ} 00^{\prime} \mathrm{S}, 40^{\circ} 30^{\prime}-$ $41^{\circ} 00^{\prime} \mathrm{W}$ ) presents a mountainous relief with altitudes up to $1200 \mathrm{~m}$ and was originally covered by dense forest (Atlantic rainforest). The region was intensely deforested, and presently only a few continuous forested areas survive (Mendes \& Padovan, 2000). Botanical collections in this region are scarce, except for recent efforts of the Museu de Biologia Mello Leitão in Espírito Santo, with intensive surveys in the municipality of Santa Teresa and adjacent areas. During an inventory of the Myrtaceae in Santa Teresa, three undescribed species were detected and are here described and illustrated.

1. Eugenia crassa Sobral, sp. nov. TYPE: Brazil. Espírito Santo: Santa Teresa, Santo Antônio, terreno do Bosa, 14 Jan. 1999, L. Kollmann \& E. Bausen 1563 (holotype, MBML; isotype, BHCB). Figure 1.

Species haec Eugeniae umbrosae O. Berg proxima, a qua inflorescentiis axillaribus terminalibusve, bracteolis ellipticis deltoideisve majoribus et foliis aveniis minoribusque recedit.

Tree 10-12 m tall; twigs and abaxial side of young leaves with arachnoid rufescent trichomes to $0.2 \mathrm{~mm}$, twigs apically terete or subquadrate, 5-8 $\mathrm{mm}$ thick. Leaves with petioles $15-18 \times 2.8-4 \mathrm{~mm}$; blades lanceolate to oblong, 140-170 × 45-75 mm, leathery, discolored when dry, adaxially glabrous, the abaxial side with trichomes that fall irregularly in mature leaves, apex widely acute to obtuse, base cuneate or obtuse; midvein plane or weakly sulcate adaxially, strongly raised and sometimes longitudinally wrinkled abaxially; lateral veins 12 to 16 on each side, scarcely or not visible on both sides, occasionally faintly raised abaxially; marginal vein $3-5 \mathrm{~mm}$ from the margin, occasionally a second vein ca. $1 \mathrm{~mm}$, the margin itself strongly revolute and with a yellowish or brownish girdle $0.2-0.5 \mathrm{~mm}$ wide. Inflorescences axillary or terminal, racemiform (bracteate shoots sensu Landrum \& Kawasaki, 1997), 5-20 × 2-5 mm, with 2 to 4 flowers. Flowers with pedicels $2-4 \times$ ca. $2 \mathrm{~mm}$; bracteoles concealing the ovary, elliptic or ovate, 7-8 $\times$ 6-8 mm, glabrous or sparsely covered with appressed rufescent trichomes $0.1-0.2 \mathrm{~mm}$, persistent at anthesis; flower buds obpyriform, ca. $15 \times 10_{-}$ $12 \mathrm{~mm}$; ovary pilose, with densely appressed rufescent 


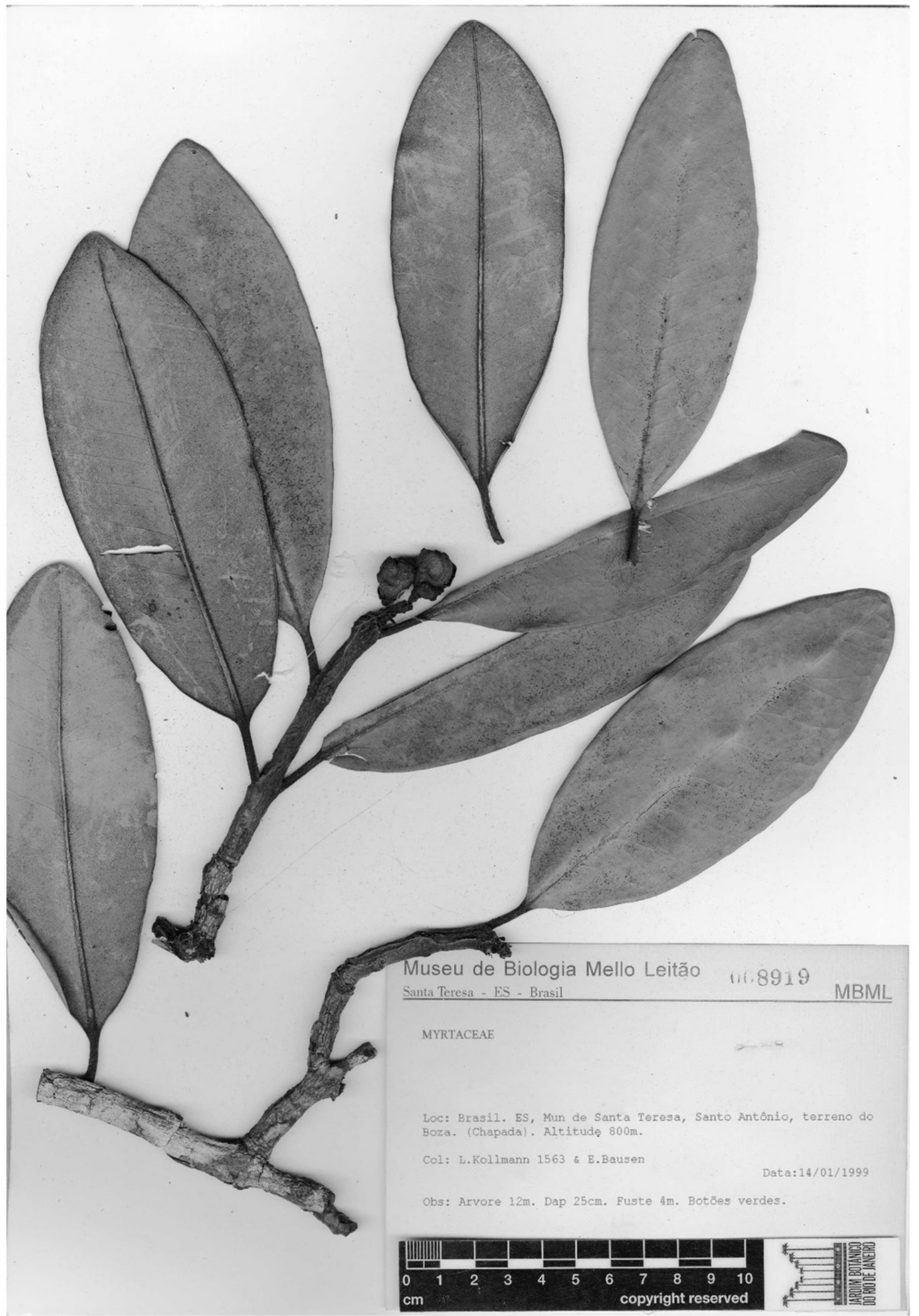

Figure 1. Eugenia crassa Sobral, isotype specimen (L. Kollmann \& E. Bausen 1563, BHCB).

trichomes to $0.1 \mathrm{~mm}$, markedly distinct from the calyx lobes, these 4, glabrous, ovate-triangular, unequal, the external pair 7-8 $\times 10-12 \mathrm{~mm}$ and the internal pair 8-9 $\times$ ca. $10 \mathrm{~mm}$; petals orbicular, 10-14 mm diam.; stamens ca. 200, 7-8 mm, anthers ovate-oblong, 1-1.3 $\times$ ca. $0.5 \mathrm{~mm}$, with one apical gland (petals and stamens measured in pre-anthesal buds; in open flowers they may be larger); staminal ring rounded, ca. 
$10 \mathrm{~mm}$ diam.; style to $10 \mathrm{~mm}$, stigma punctiform; ovary bilocular with ca. 30 ovules per locule. Fruits globose or somewhat oblate, $25-28 \times$ ca. $30 \mathrm{~mm}$, single-seeded, immature in the collections examined; seed globose-elliptic, $20-22 \times$ ca. $20 \mathrm{~mm}$; embryo with 2 fused cotyledons and no visible hypocotyl.

Distribution, habitat, and phenology. Eugenia crassa is a tree from Atlantic montane forests at altitudes of $750-800 \mathrm{~m}$. The new taxon is currently known only from the municipality of Santa Teresa, and is noted to flower in January and fruit in October.

IUCN Red List category. According to IUCN Red List criteria (IUCN, 2001), Eugenia crassa is assessed here as Endangered (EN), fitting criteria Blab(iii). Its known area of occurrence is smaller than $5000 \mathrm{~km}^{2}$ (criterion B1), since the municipality of Santa Teresa has an area of $695 \mathrm{~km}^{2}$ (IBGE, 2010), and it grows in a fragmented habitat (criterion a) with continuing decline in extension (criterion b[iii]), since only $18 \%$ of the area of Santa Teresa retains its original vegetation (Mendes \& Padovan, 2000: 16).

Etymology. The specific epithet is taken from the Latin "crassus," meaning "thick," alluding to the overall aspect of the exsiccatae, with leathery leaves and robust twigs.

Taxonomic affinities. Eugenia crassa, due to the overall aspect of the leaves and the indumentum on the leaves and flowers, is apparently related to $E$. umbrosa 0 . Berg, a species collected in the nearby state of Rio de Janeiro (Berg, 1857-1859: 582). The two species can be distinguished by the characters described in the following key couplet:

la. Inflorescences ramiflorous, the axes to $2 \mathrm{~mm}$; bracteoles ovate, to $2 \mathrm{~mm}$; leaves with petioles to $8 \mathrm{~mm}$ and blades $170-200 \times 48-50 \mathrm{~mm}$, the venation clearly manifest on both faces ..... E. umbrosa

lb. Inflorescences axillary or terminal, axes 5-20 mm; bracteoles elliptic or ovate, $7-8 \mathrm{~mm}$; leaves with petioles 15-18 mm and blades 140-170 × 45$75 \mathrm{~mm}$, the venation scarcely visible on both faces................... E. crassa

Paratypes. BRAZIL. Espírito Santo: Santa Teresa, Santo Antônio, Terreno do Bosa, 7 Oct. 1998, L. Kollmann, E. Bausen \& W. Pizziolo 714 (MBML, MO), L. Kollmann, E. Bausen \& W. Pizziolo 718 (BHCB, MBML).

2. Myrcia santateresana Sobral, sp. nov. TYPE: Brazil. Espírito Santo: Santa Teresa, São Lourenço, Reserva Biol. de São Lourenço, trilha do Caravagem, 3 Feb. 1999, L. Kollmann, E. Bausen \& W. Pizziolo 1793 (holotype, MBML; isotype, BHCB). Figure 2.

Species haec Myrciae badiae (O. Berg) N. Silveira proxima, a qua foliis minoribus discoloribusque nervis marginalibus interruptis et floribus glabris minoribus hypanthio nullo recedit.

Tree 9-12 m tall; plants glabrous except for scattered simple hyaline trichomes $0.1-0.3 \mathrm{~mm}$ on the inflorescences; twigs ochraceous or pale yellow, moderately exfoliating, terete, 1-2 mm thick. Leaves with blades lanceolate to lanceolate-obovate, 80-140 $\times 35-50 \mathrm{~mm}$, strongly discolorous in dried specimens, apex acute to acuminate, base cuneate; midvein sulcate adaxially and raised abaxially; lateral veins 12 to 15 at each side, evident on both faces and raised abaxially; marginal veins 2 , the inner one somewhat discontinuous, 3-4 $\mathrm{mm}$, the outer one ca. $1 \mathrm{~mm}$ from the margin; petioles 8-10 $\times$ 1.5-1.7 mm. Inflorescences terminal, paniculiform, up to 3 times ramified, the main axis 100-160 $\times 1-3 \mathrm{~mm}$; bracts lanceolate, ca. $0.8 \times 0.3 \mathrm{~mm}$, occasionally persisting. Flowers sessile or with pedicels to $0.5 \times 0.3 \mathrm{~mm}$; bracteoles lanceolate, 0.5-0.7 $\times$ ca. $0.3 \mathrm{~mm}$, deciduous at anthesis; flower buds globose to obovate, $1.5-2 \times$ ca. $1.5 \mathrm{~mm}$; calyx lobes 5 , unequal in size, triangular to rounded, 1-1.5 $\times$ 1-2 mm, reflexed at anthesis; petals white, rounded to obovate, ca. $2 \times 2 \mathrm{~mm}$; stamens ca. 50 (mostly fallen; estimated by scars on the staminal ring), ca. $2 \mathrm{~mm}$, anthers elliptic, ca. $0.4 \times 0.2 \mathrm{~mm}$, apparently devoid of apical glands; staminal ring rounded, 1-1.3 mm diam.; calyx tube absent; style 3-4 mm, stigma punctiform; ovary bilocular with 2 centrally attached ovules per locule. Fruits globose, 5-6 mm diam., immature in the collections examined; seeds 1 to 2 , with membranous testa; embryo immature, not distinguishable.

Distribution, habitat, and phenology. Myrcia santateresana is a tree from montane forests at altitudes of $750-850 \mathrm{~m}$. It is presently known only from the municipality of Santa Teresa. The new species was observed to flower in December and February, with fruits in March.

IUCN Red List category. This species can be considered as Endangered (EN), according to IUCN Red List criteria (IUCN, 2001), fitting criteria Blab(iii); for an explanation of these criteria see the text under Eugenia crassa, since the conditions described for this species also apply to Myrcia santateresana.

Taxonomic affinities. Myrcia santateresana, due to the shape of its leaves and venation pattern, is apparently related to $M$. badia (O. Berg) N. Silveira, native from Bahia (Berg, 1857-1859: 547, as Aulomyrcia badia 0. Berg). The two species can be distinguished by the characters described in the following key couplet:

1a. Leaves 150-200 × 35-55 mm, concolorous or not markedly discolored; lateral veins to 20 or more at 


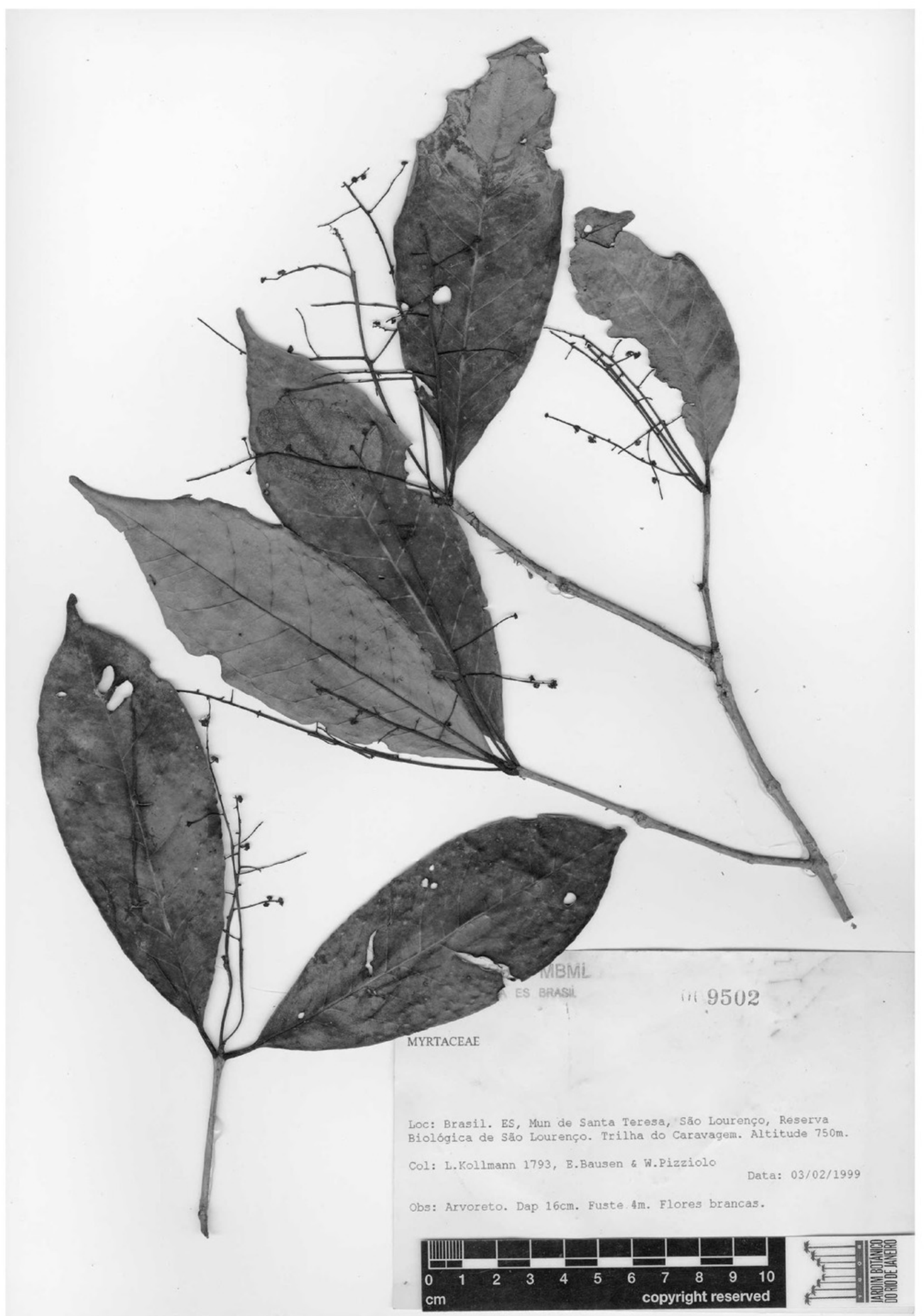

Figure 2. Myrcia santateresana Sobral, isotype specimen (L. Kollmann, E. Bausen \& W. Pizziolo 1793, BHCB).

each side, forming a continuous marginal vein; flowers pilose, sessile at the apex of inflorescence branches; buds to $4 \mathrm{~mm}$; calyx tube present ... M. badia

1b. Leaves $80-140 \times 35-50 \mathrm{~mm}$, markedly discolorous; lateral veins to 15 at each side, forming a discontinuous inner marginal vein; flowers gla- brous, sessile along the inflorescence branches; buds to $2 \mathrm{~mm}$; calyx tube absent .... M. santateresana

Paratypes. BRAZIL. Espírito Santo: Santa Teresa, Reserva Biol. Caixa D'Água, trilha do Caravagem, 29 Dec. 1998, L. Kollmann \& E. Bausen 1371 (BHCB, MBML); 
cabeceira do 25 de julho, terreno do Furlani, 11 Mar. 1999, L. Kollmann, E. Bausen \& W. Pizziolo 2153 (MBML, MO).

3. Myrcia tumida Sobral, sp. nov. TYPE: Brazil. Espírito Santo: Santa Teresa, Valsugana Velha, Reserva Biol. Santa Lúcia, 28 Jan. 1999, L. Kollmann, E. Bausen \& W. Pizziolo 1736 (holotype, MBML; isotype, BHCB). Figure 3.

Species haec Myrciae guianensi (Aubl.) DC. proxima, a qua florum lobis calycinis adaxialiter praesertim dimidio superiore planis vel convexis et tumidis, fructibus majoribus et petiolis longioribus recedit.

Shrub or treelet to $5 \mathrm{~m}$ tall; plants glabrous except for very scattered rufescent dibrachiate trichomes to $0.4 \mathrm{~mm}$ in young leaves and grayish or brownish simple trichomes ca. $0.1 \mathrm{~mm}$ at the adaxial side of calyx lobes; twigs terete, grayish or brownish, 1-2 mm thick. Leaves with petioles 10-13 × 1-1.2 mm; blades elliptic-oblong, oblong-obovate, or widely elliptic, 80-110 × 30-60 mm, concolorous or slightly discolored when dry and with evident glandular dots $0.1-0.2 \mathrm{~mm}$ diam., apex obtuse to widely acute, rarely retuse, base cuneate; midvein plane or sulcate, rarely slightly raised adaxially and evident abaxially; lateral veins 15 to 17 at each side, scarcely evident to weakly raised on both sides; marginal vein 1-2 mm from the sometimes revolute margin. Inflorescences with 3 to 7 flowers, sometimes reduced to only 1 flower, then the axis looking like a pedicel to $15 \mathrm{~mm}$, more commonly racemiform or paniculiform, then ramified only once, the axis $35-65 \times$ ca. $1.5 \mathrm{~mm}$; flowers sessile or pedicels $2-2.5 \times$ ca. $0.5 \mathrm{~mm}$; bracteoles not seen; flower buds globose or obovate, 3-4 $\times$ ca. $4 \mathrm{~mm}$, with visible glandular dots; calyx lobes ovate, erect at anthesis, sometimes unequal in size, $1-2 \times$ ca. $2 \mathrm{~mm}$, internally with trichomes to $0.1 \mathrm{~mm}$, the apex adaxially plane or convex, in this case seeming a little swollen and to $1 \mathrm{~mm}$ thick; petals white, rounded or obovate, 3-4 × 2-3 mm; stamens ca. $80,4-5 \mathrm{~mm}$, the anthers globose, ca. $0.3 \times$ $0.3 \mathrm{~mm}$, with one apical gland; calyx tube present, 0.8-1 mm deep; style 7-8 mm, the stigma punctiform and finely papillate; ovary 3 -locular, with 2 centrally attached ovules per locule. Fruits globose or oblate, yellowish as far as known, 10-17 × 10-18 mm; seeds widely reniform, to $10 \times 7-8 \mathrm{~mm}$, the testa brown, shining; embryo with 2 folded cotyledons and hypocotyl.

Distribution, habitat, and phenology. Myrcia tumida is a tree from Atlantic montane forests at altitudes from 600-950 m. It has been collected only from the municipalities of Santa Leopoldina and Santa
Teresa. The new species flowers in January and fruits in May and July.

IUCN Red List category. According to IUCN Red List criteria (IUCN, 2001), this species can be considered as Endangered (EN), fitting criteria Blab(iii), since its known area of occurrence is smaller than $5000 \mathrm{~km}^{2}$ (criterion B1), and since the municipalities of Santa Leopoldina and Santa Teresa have, respectively, areas of $716 \mathrm{~km}^{2}$ and $695 \mathrm{~km}^{2}$ (IBGE, 2010). Myrcia tumida grows in a fragmented habitat (criterion a) with a continuing decline in extension (criterion b[iii]), since only $18 \%$ of the area of Santa Teresa still retains its original vegetation (Mendes \& Padovan, 2000: 16) and, since the occupation history and land use of the municipality of Santa Leopoldina is similar, possibly only a small part of its original vegetation has remained.

Etymology. The specific epithet is taken from the Latin "tumidus," meaning "swollen," alluding to the form of the calyx lobes.

Taxonomic affinities. Myrcia tumida, due to the form of its leaves and venation, is related to the widespread $M$. guianensis (Aubl.) DC. The two species can be distinguished by the characters described in the following key couplet:

1a. Calyx lobes uniformly concave, never swollen and complanate distally; mature fruits globose, to $10 \mathrm{~mm}$ diam.; leaves with blades to $70 \times 20 \mathrm{~mm}$ and petioles to $6 \times 1 \mathrm{~mm} \ldots \ldots \ldots$. guianensis

1b. Calyx lobes concave only proximally or not concave at all, swollen and complanate to convex distally; mature fruits globose or oblate, $10-17 \times$ $10-18 \mathrm{~mm}$; leaves with blades to $110 \times 60 \mathrm{~mm}$ and petioles to $13 \times 1.2 \mathrm{~mm} \ldots \ldots \ldots$. tumida

Paratypes. BRAZIL. Espírito Santo: Santa Leopoldina, Cachoeira da Fumaça, 3 July 1984, W. Boone 245 (BHCB, MBML); Santa Teresa, mata do Tabajara, Jan. 1997, M. Sobral, C. Bassi, H. Boudet Fernandes \& G. Hupp 8277 (BHCB, K, MBM, MO); Cabeceira do rio Bonito, radar, 31 Jan. 2002, L. Kollmann \& E. Bausen 5451 (BHCB, MBML); Nova Lombardia, Reserva Biológica Augusto Ruschi, trilha da divisa, 24 May 2002, R. Vervloet, W. Pizziolo \& E. Bausen 287 (MBML, MO), 10 Apr. 2003, R. Vervloet, E. Bausen \& W. Pizziolo 2217 (MBML), 28 July 2004, L. Kollmann 6598 (MBML).

Acknowledgments. My thanks to the staff of the Museu de Biologia Mello Leitão (MBML), Santa Teresa, for their constant goodwill and cooperation with my work, especially Hélio Boudet Fernandes and Ludovic Kollmann; to all the collectors of the specimens cited; to Alexander Sennikov (LE), who kindly sent me images of the type of Aulomyrcia badia; and to Eve Lucas (K) for sharing with me her insightful concepts on Myrcia DC. ex Guill. I am also indebted to Rafaela Forzza and Erika von Sohsten 


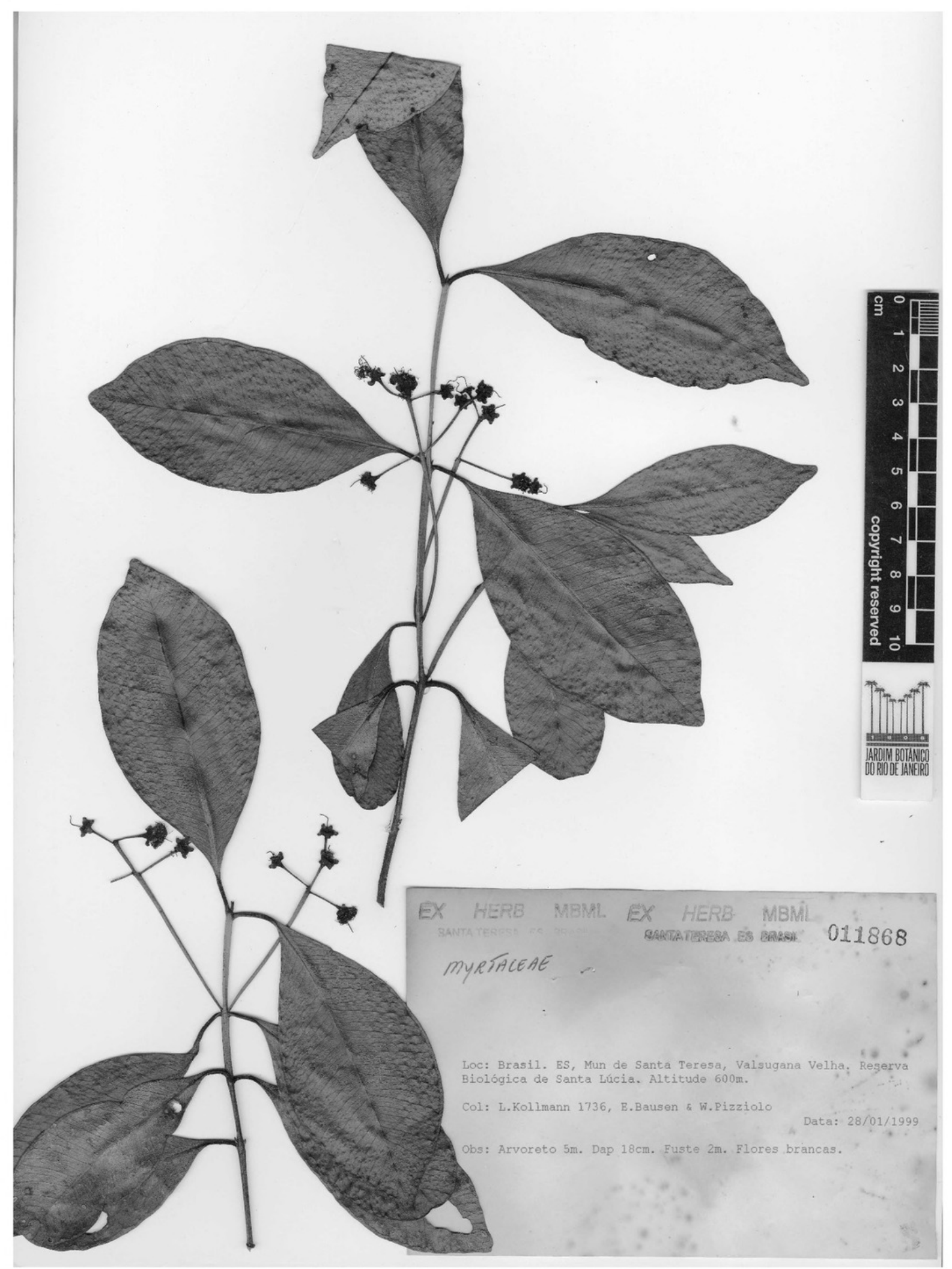

Figure 3. Myrcia tumida Sobral, isotype specimen (L. Kollmann, E. Bausen \& W. Pizziolo 1736, BHCB).

Medeiros (RB) for their help in preparing the figures; Beth Parada and Allison Brock for their editorial assistance; and Roy Gereau for his corrections to the Latin diagnoses.

\section{Literature Cited}

Berg, O. C. 1857-1859. Myrtaceae. In C. F. P. von Martius (editor), Flora Brasiliensis, Vol. 14(1): 1-656. F. Fleischer, Leipzig. 
Instituto Brasileiro de Geografia e Estatística (IBGE). 2010. IBGE Cities@. <http://www.ibge.gov.br/cidadesat/default. php>, accessed 6 July 2010.

IUCN. 2001. IUCN Red List Categories and Criteria, Version 3.1. Prepared by the IUCN Species Survival Commission. IUCN, Gland, Switzerland, and Cambridge, United Kingdom.
Landrum, L. R. \& M. L. Kawasaki. 1997. The genera of Myrtaceae in Brazil: An illustrated synoptic treatment and identification keys. Brittonia 49: 508-536.

Mendes, S. L. \& M. P. Padovan. 2000. A Estação Biológica de Santa Lúcia, Santa Teresa, Espírito Santo. Bol. Mus. Biol. Mello Leitão, Nova Sér. 11/12: 7-34. 


\section{$2 \mathrm{BHL}$ Biodiversity Heritage Library}

Sobral, Marcos. 2010. "Three New Montane Forest Myrtaceae from Espírito Santo, Brazil." Novon a journal of botanical nomenclature from the Missouri Botanical Garden 20, 338-344.

View This Item Online: https://www.biodiversitylibrary.org/item/123332

Permalink: https://www.biodiversitylibrary.org/partpdf/122036

\section{Holding Institution}

Missouri Botanical Garden, Peter H. Raven Library

\section{Sponsored by}

Missouri Botanical Garden

\section{Copyright \& Reuse}

Copyright Status: Permission to digitize granted by rights holder Rights: https://www.biodiversitylibrary.org/permissions

This document was created from content at the Biodiversity Heritage Library, the world's largest open access digital library for biodiversity literature and archives. Visit BHL at https://www.biodiversitylibrary.org. 